DOI: 10.17707/AgricultForest.62.2.24

\author{
Tatjana POPOVIĆ, Slavko MIJOVIĆ, \\ Danijela RAIČEVIĆ, Radmila PAJOVIĆl
}

\title{
IMPACT OF CLIMATE FACTORS ON YIELD AND QUALITY OF VINE VARIETY CABERNET SAUVIGNON IN PODGORICA WINE GROWING REGION
}

\section{SUMMARY}

The influence of climatic factors on grape yield, grape cluster weight, sugar and acidity content in stum in variety Cabernet Sauvignon was measured in period from 2011 to 2013 at the experimental field of Biotechnical Faculty in Podgorica. The study was conducted in the vineyard of the Biotechnical Faculty in Podgorica in the stage of full grape maturity.

The highest grape yield as well as the cluster weight were measured in $2012\left(1.2 \mathrm{~kg} / \mathrm{m}^{2}\right.$ and $125 \mathrm{~g}$ respectively), while the lowest values were measured in $2013-0.88 \mathrm{~kg} / \mathrm{m}^{2}$ and $92 \mathrm{~g}$. Highest sugar content in stum was measured in 2011, and lowest in 2013. The highest acid content was measured in 2013 (6.50 $\mathrm{g} / \mathrm{l}$ ) as a result of heavy rainfall during the growing season, especially in August and September. Differences between the studied parameters were statistically significant.

The results showed that the yield and quality of grapes were in direct relation with the weather conditions in certain years of experiments.

Keywords: Cabernet Sauvignon, climatic factors, yield, quality of grapes.

\section{INTRODUCTION}

Due to favourable soil and climatic conditions Podgorica wine growing region was always considered an area very suitable for vine growing. However, the climatic parameters are significantly fluctuating leading to deterioration of usual weather conditions in recent years. There are many indicators confirming that the climate in this wine growing region is changing rapidly: the number of days with tropical temperature is rising, periods of drought are longer and more frequent especially during the summer months, the number of days without rain is increasing, but also the intensity of precipitation. Precipitation is particularly intense during the winter months and often has flood character (Micev, 2014).

Climate change is taking place in every part of the globe in a greater or lesser extent - from the equator to the poles (Gearheard et al., 2010). The consequences of climate change are evident in many viticulture areas of the

\footnotetext{
1 Tatjana POPOVIĆ, (corresponding author: tatjanapopovic@t-com.me), University of Montenegro, Biotechnical Faculty, Slavko MIJOVIĆ, University of Montenegro, Biotechnical Faculty, Danijela RAIČEVIĆ, University of Montenegro, Biotechnical Faculty, Radmila PAJOVIĆ, University of Montenegro, Biotechnical Faculty. MONTENEGRO

Notes: The authors declare that they have no conflicts of interest. Authorship Form signed online.
} 
world and predominantly manifested in the changes occurring in the phenophases of vines, as well as the harvest date (Jones et al., 2007). Although Montenegro, as a small geographical area, does not affect the global climate change, it does increasingly suffer from its negative impact, and consequently vine production as well.

Numerous studies worldwide predict that extreme future weather conditions will be more frequent, and negative impact on agricultural production will be more noticeable. All listed above impose a constant need for research of impact of changing climate on agro-technological and economical characteristics of the dominantly cultivated varieties of vine in Montenegro, and therefore the variety Cabernet Sauvignon as well, which is one of the leading vine varieties for the production of high quality red wines. However, it should always be considered that in addition to agro ecological conditions (relief, exposure, temperature sums, radiation, physical and mineral properties of soil), agro biological, economical and technological properties of grape vines are significantly affected by the level of applied ampelotechnics, the type of rootstock, growth form, the pruning technique and many others. (Brighenti et al., 2010; Van Leeuwen and Seguin, 1994).

The aim of this study is to evaluate the impact of major climatic parameters on the yield and quality of grape variety Cabernet Sauvignon, especially during the vegetation season in Podgorica wine growing region.

\section{MATERIAL AND METHODS}

The study of the influence of climatic factors on the yield and quality of grape variety Cabernet Sauvignon was conducted in 2011, 2012 and 2013. The study was performed at the experimental field of the Biotechnical Faculty in Podgorica. Experimental vineyard was planted in 2005 with the planting distance of $2.5 \mathrm{~m}$ between rows and $1 \mathrm{~m}$ within rows. Growing form of vine is double horizontal cordon with trunk height of about $80 \mathrm{~cm}$. Mixed pruning was applied. Tests were carried out on 30 vines, that is, three repetitions with 10 vines.

During the three-year study grape yield was examined $(\mathrm{kg} / \mathrm{m} 2)$, cluster weight $(\mathrm{g})$, sugar $(\%)$ and acid content $(\mathrm{g} / \mathrm{l})$ in stum. Yield was obtained by measuring the harvested grapes and calculating grape weight per $\mathrm{m} 2$, cluster weight was determined from the ratio of the yield of ten vines and number of grape clusters. The sugar content in the grape juice was determined with areometrically (Oeschle must balance), and proportion of the total acid in the grape juice by neutralization of acids and their salts with $n / 10 \mathrm{NaOH}$ solution using bromothymol blue indicator.

In the analysis of climate in Lješkopolje, data from weather stations in Podgorica were used. Statistical analysis of the results was performed using analysis of variance and LSD test. 


\section{RESULTS AND DISCUSSION}

Yield quantity and quality is heavily influenced by climate and the prevailing meteorological conditions in production regions (Mirošević and Karoglan Kontić, 2008). Air temperature exerts dominant influence on vines apropos vine phenological dynamics, and in current climate changing condition, heat regime changes are the most pronounced.

Tab.1. Mean monthly, annual and air temperature in vegetation period $\left({ }^{\circ} \mathrm{c}\right)$

\begin{tabular}{|c|c|c|c|c|c|c|c|c|c|c|c|c|c|c|c|}
\hline \multirow[b]{2}{*}{ Year } & \multicolumn{12}{|c|}{ Month } & \multirow{2}{*}{ 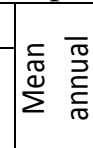 } & \multirow{2}{*}{ 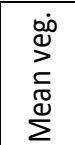 } & \multirow{2}{*}{ 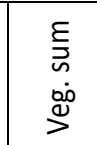 } \\
\hline & 1 & II & III & IV & V & VI & VII & VIII & IX & $x$ & XI & XII & & & \\
\hline 111 & \begin{tabular}{|l|l}
5.8 \\
\end{tabular} & 7.8 & 1.7 & 16.8 & 0.3 & 5.6 & .2 & 9.3 & 26.3 & 16.3 & 9.9 & \begin{tabular}{|l|}
8.0 \\
\end{tabular} & $\begin{array}{ll}17.0 \\
\end{array}$ & \begin{tabular}{|l|l}
23.1 \\
\end{tabular} & 4947.1 \\
\hline 12 & 4. & 3 & 13.1 & 14.5 & 19.9 & 27.3 & 30.4 & 9.7 & 23.9 & 18.2 & 13.3 & 5.6 & 16.2 & 23.4 & 5007 \\
\hline 13 & 6.7 & 7.7 & 10.8 & 17.1 & 20.1 & 24.5 & 28.5 & 28.8 & 21.3 & \begin{tabular}{|l|l}
16.7 \\
\end{tabular} & 12.5 & 6.6 & 16.8 & 22.4 & 4793.6 \\
\hline $\begin{array}{l}011- \\
013 \\
\end{array}$ & 5.8 & 6.2 & 8.5 & 16.1 & 20.1 & 25.8 & 28.7 & 29.3 & 23.8 & 17.0 & 11.9 & 6.7 & 16.5 & 23.0 & |4916.1 \\
\hline 1985- & 6.2 & 7.4 & 10.5 & 15.8 & .5 & 4 & 28.0 & 7.6 & 21.6 & .2 & 10.8 & 7.3 & 6.3 & 22.0 & 4715.3 \\
\hline
\end{tabular}

Table 1 clearly shows that air temperature in Podgorica wine growing region is in constant growth, especially in the summer period. If we analyze climate anomalies, expressed through the differences in the values of climate parameters between the multi-year average (1985-2010) and the period from 2011 to 2013, we come to the conclusion that the climate in this wine-growing region is rapidly changing. Compared to long-term averages, average annual air temperature in 2011 was $0.7^{\circ} \mathrm{C}$ higher than the long term average, in $20130.5^{\circ} \mathrm{C}$, while in 2012 was at the level of long-term averages.

The mean temperature in vegetation period in the three-year average was $23^{\circ} \mathrm{C}$ which is $1^{\circ} \mathrm{C}$ more than in the multi-year average. In the second research year, medium temperature in vegetation period was $23.4^{\circ} \mathrm{C}$, and was slightly higher than in the first year $\left(23.1^{\circ} \mathrm{C}\right)$ and significantly higher than in the third year in which the mean temperature during the vegetation period was $22.4^{\circ} \mathrm{C}$.

Tab. 2. Absolute maximum air temperatures

\begin{tabular}{|c|c|c|c|c|c|c|c|c|c|c|c|c|c|}
\hline \multirow{2}{*}{ Year } & \multicolumn{10}{|c|}{ Mear } \\
\cline { 2 - 14 } & I & II & III & IV & V & VI & VII & VIII & IX & X & XI & XII & max \\
\hline 2011 & 16.6 & 21.3 & 23.7 & 27.6 & 31.5 & 37.6 & 39.9 & 41.2 & 37.8 & 31.0 & 21.9 & 16.8 & 41.2 \\
\hline 2012 & 15.7 & 19.3 & 26.3 & 31.1 & 33.5 & 38.3 & 40.7 & 44.0 & 36.1 & 33.6 & 22.6 & 15.4 & 44.0 \\
\hline 2013 & 16.7 & 17.2 & 20.3 & 32.6 & 34.1 & 38.4 & 39.4 & 41.3 & 31.9 & 29.2 & 24.8 & 17.8 & 41.3 \\
\hline
\end{tabular}

The average sum of active temperatures during the vegetation period for the period $1985-2010$ was $4715.3^{\circ} \mathrm{C}$, while in the studied period was significantly higher $-4916.1^{\circ} \mathrm{C}$. In the studied period, the highest temperature sum in vegetation period was in $2012\left(5007.6^{\circ} \mathrm{C}\right)$. Table 2 shows that in the period May - Aug - July - August in 2012 was measured significantly higher maximum air 
temperature compared to the same period in 2011 and 2013. In other months, the maximum air temperatures were at the same level. In 2012, in the period May September, was also measured the highest minimum air temperature (tab. 3).

Tab. 3. Absolute minimum air temperatures

\begin{tabular}{|c|c|c|c|c|c|c|c|c|c|c|c|c|c|}
\hline \multirow{2}{*}{ Year } & \multicolumn{12}{|c|}{ Months } & \multirow{2}{*}{$\begin{array}{l}\text { Year } \\
\text { min }\end{array}$} \\
\hline & I & II & III & IV & $\mathrm{V}$ & VI & VII & VIII & IX & X & XI & XII & \\
\hline 2011 & -3.0 & -3.1 & -2.3 & 4.7 & 9.9 & 16.7 & 14.9 & 16.9 & 17.5 & 2.9 & 0.3 & -2.6 & -3.1 \\
\hline 2012 & -5.5 & -5.7 & 2.5 & 0.4 & 10.7 & 14.9 & 19.6 & 17.7 & 10.9 & 7.2 & 4 & -5.5 & -5.7 \\
\hline 2013 & -2.3 & -2.3 & -0.6 & 8.6 & 10.0 & 11.3 & 16.9 & 18.5 & 11.1 & 1.7 & -1 & -3.3 & -3.3 \\
\hline
\end{tabular}

Jovović et al. (2015) state that the number of tropical days and duration of the warm tropical waves have significantly increased in Podgorica. They further alleged that $59 \%$ of June, $87 \%$ of July and $86 \%$ of August days had a tropical character, and that $15 \%$ of the days during June, $40 \%$ of the days in July and $45 \%$ of the days during August had high tropical temperatures (maximum temperature reaches and passes $35^{\circ} \mathrm{C}$ ). Also, the average number of summer days (maximum temperature during the day reaches and exceeds $25^{\circ} \mathrm{C}$ ), has increased from 129 to 145 days.

Tab. 4. The monthly, annual and precipitations during vegetation period (mm)

\begin{tabular}{|c|c|c|c|c|c|c|c|c|c|c|c|c|c|c|}
\hline \multirow[b]{2}{*}{ Year } & \multicolumn{12}{|c|}{ Months } & \multirow{2}{*}{ 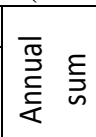 } & \multirow{2}{*}{ 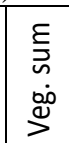 } \\
\hline & I & II & III & IV & V & VI & VII & VIII & IX & X & XI & XII & & \\
\hline 2011 & 79.5 & 113.8 & 100.5 & 44.1 & 89.5 & 25.8 & 31.4 & 2.1 & 43.3 & 73.6 & 37.1 & 254.2 & 894.9 & 309.8 \\
\hline 2012 & 60.3 & 200.9 & 0.0 & 351.2 & 132.0 & 33.7 & 11.3 & 0.5 & 86.6 & 296.3 & 285.8 & 305.0 & 1763.6 & 911. \\
\hline 2013 & 324.3 & 246.8 & 518.6 & 101.2 & 211.2 & 51.0 & 10.3 & 123.1 & 178.4 & 239.3 & 341 & 45.8 & 2391.0 & 914.5 \\
\hline \begin{tabular}{|l}
$2011-$ \\
2013 \\
\end{tabular} & 219.8 & 203.3 & 220.5 & 165.5 & 144.2 & 36.8 & 17.6 & 41.9 & 102.7 & 203.0 & 309.0 & 231.0 & 1683.1 & 71 \\
\hline $\begin{array}{l}1985- \\
2010\end{array}$ & 195.1 & 190 & 210.9 & 103.9 & 68.5 & 102.1 & 21.3 & 56.6 & 115.4 & 181.6 & 289.3 & 242.8 & 1777 & 4 \\
\hline
\end{tabular}

The results given in Table 4 show that in Podgorica wine growing region mean annual rainfall for the period 1985-2010 was $1777.5 \mathrm{~mm}$, while in the period studied (2011-2013) was lower and was $1683.1 \mathrm{~mm}$. These data show that in precipitation amounts between the observed periods there were no significant changes, but the changes were significant in the precipitation regime pronounced rainy and drought periods during the year. In 2011, the annual amount of rainfall was only $894.91 / \mathrm{m}^{2}$, or $882.61 / \mathrm{m}^{2}$ less than long-term averages. In the second year, the annual amount of precipitation $(1763.6 \mathrm{~mm})$ was at the level of multi-year average, while in the third year it was significantly higher and was $2,3911 / \mathrm{m}^{2}$.

When analysing rainfall in the vegetation period (tab. 4) it is clear that in 2011 precipitation level of only $309.81 / \mathrm{m} 2$ was significantly lower than in 2012 and 2013 in which during the vegetation period was measured $911.61 / \mathrm{m} 2$ and $914.5 \mathrm{l} / \mathrm{m} 2$, respectively. It is interesting to note that in 2013 , for the first three 
months, it was measured record amount of rain - $1090 \mathrm{l} / \mathrm{m} 2$. Most of the rainfall in this year fell in March - $518.6 \mathrm{~mm}$; three and a half times more than the usual rainfall for this month. Since the measuring of rainfall exists in Montenegro (for 64 years) it has not happened that this much rain falls in March (Micev, 2015).

The average amount of precipitation during the vegetation period from 2011 to 2013 was $711.8 \mathrm{l} / \mathrm{m} 2$. Although in the studied period, compared to the multi-year average $(649.5 \mathrm{l} / \mathrm{m} 2)$, was registered more rainfall, this does not mean that the vines in these years were sufficiently provided with water. Namely, in 2011 and 2012, the distribution of rainfall was quite unfavourable, with a strong deficit in the warmest period of the year.

Grape yield per area unit, as an absolute indicator of productivity of varieties, is conditioned by a number of factors. Among the more important are biological characteristic of the variety and environmental conditions in the studied years. The results in Table 5 show that the yield of grapes was in accordance with the weather conditions in studied years. The lowest yield of grapes $(0.83 \mathrm{~kg} / \mathrm{m} 2)$ was measured in 2013 , with highest precipitation, both on annual basis, and during the vegetation period. This year there was a very high intensity of plant diseases, which, along with noticeable reduction in yield and increased use of chemicals, significantly increased the production costs. The highest yield was measured in $2012(1.20 \mathrm{~kg} / \mathrm{m} 2)$, while in 2011 it was $0.96 \mathrm{~kg} /$ $\mathrm{m} 2$. Statistical analysis of data showed that the yield of grapes in 2012 was significantly higher compared to 2013, and less significant compared to 2011. The difference in the yield of grapes between the first and the third year of study did not have the statistical significance for any level of probability. Yields in all years of study have been at the level for the variety Cabernet Sauvignon cited by other authors (Pejović, 1996; Burić, 1995; Cindrić, 2000; Mirošević, 2008 etc.).

Tab. 5. The yield and quality of grape variety Cabernet Sauvignon

\begin{tabular}{|c|c|c|c|c|}
\hline Year & $\left(\mathrm{kg} / \mathrm{m}^{2}\right)$ & $\begin{array}{c}\text { Grape cluster } \\
\text { weight }(\mathrm{g})\end{array}$ & $\begin{array}{c}\text { Sugar content } \\
(\%)\end{array}$ & $\begin{array}{c}\text { Acid content } \\
(\mathrm{g} / \mathrm{l})\end{array}$ \\
\hline 2011 & 0.96 & 104 & 24.10 & 5.9 \\
\hline 2012 & 1.20 & 125 & 23.00 & 6.0 \\
\hline 2013 & 0.83 & 89 & 21.0 & 6.5 \\
\hline Averag & 1.00 & 106 & 22.7 & 6.1 \\
e & \multicolumn{5}{|c|}{$\begin{array}{l} \\
\text { LSD 0.05 } \\
\text { Grape yield }\end{array}$} & $\begin{array}{c}\text { LSD } 0.01 \\
\text { Grape cluster weight }\end{array}$ & 15.3 & 22.2 & \\
Sugar content in stum & 0.81 & 1.18 & \\
Acid content in stum & 0.39 & 0.58 & \\
\hline
\end{tabular}

The results of the study of average cluster weight of variety Cabernet Sauvignon are given in Table 5. Analyzing the average values in years of study it can be noted that in 2012 cluster weight was significantly higher than in 2013 
and less significant in comparison to 2011. The higher cluster weight in first two years of the experiment (125 and $104 \mathrm{~g}$ respectively) was due to significantly more favourable environmental conditions in those years, particularly temperature. During these years, the average air temperatures in the vegetation period were significantly higher compared to 2013. The results are consistent with the results reported by Popović et al, 2013, which stated that the cluster weight of variety Vranac in Podgorica wine growing region was higher in climatically favourable years. The average weight of clusters in this research was at the level of values that the variety Cabernet Sauvignon has in the same agroecological conditions as stated by Pejović et al., 1996 and Pajović et al., 2009. According to Božinović (2010) the average cluster weight of variety Cabernet Sauvignon is ranging from 90 to $120 \mathrm{~g}$, which also supports the results obtained.

Trough influence on physiological processes of vine, ecological potential of wine growing regions significantly affects the quality of grapes, primarily the content of sugars and acids. The amount of sugar in grapes, apart from the variety, greatly depends on the degree of maturity and health status of grapes, as well as of the climatic conditions in the ripening stage of grapes (Ranković Vasić, 2011).

Based on the results shown in Table 5, the highest sugar content of the grapes was measured in $2011(24,10 \%)$ and the lowest in $2013(21.00 \%)$. This is the direct consequence of the variation in weather conditions that prevailed in years of performing experiments. In 2013, with the lowest mean air temperature in vegetation period and the highest amount of precipitation in the vegetation period, the sugar content in stum was lowest. Similar results were reported by Vukosavljević et al. (2011) who measured higher sugar content in years with higher mean temperatures in vegetation period. The importance and impact of growing conditions on the yield and quality of grapes indicate Santalucia et al. (2007) and Mota et al. (2008) as well.

Acids in stum are an important indicator of the quality of grapes, as taste and harmony of the wine produced depends on their presence. The results of three-year research showed that the average content of acids in stum was satisfying and typical for the variety Cabernet Sauvignon grown in the agro ecological conditions of Podgorica wine growing region. The highest content of acids was measured in $2013-6.50 \mathrm{~g} / \mathrm{l}$, as a result of higher precipitation during the vegetation period, especially in August and September (123.1 and $178.41 / \mathrm{m}^{2}$ respectively). Such conditions have significantly affected the quality of the grapes, primarily the acid content. Statistical analysis of data revealed that in 2013 the acid content was significantly higher compared to the other years studied. These results are consistent with the results of Pejović et al., (1996) and Pajović et al., (2014). However, Mirošević et al., (2008) reported higher values for the content of acids in grape variety Cabernet Sauvignon (7-9 g/l), which was probably a consequence of different agro-ecological conditions in which they conducted their research. 


\section{CONCLUSIONS}

Based on the research done, it can be concluded:

The average yield of grapes in the three-year period was $10 \mathrm{t} / \mathrm{ha}$, sugar content $22.7 \%$, and the acid content $6.10 \mathrm{~g} / \mathrm{l}$. Yield and cluster weight were lowest in 2013, which is explained by the large amount of rainfall during the vine vegetation period.

Very high sugar content was measured in 2011 and 2012 (24.1 and 23.0\% respectively) as a result of higher average air temperature in the vine vegetation period.

The highest acid content was measured in 2013 as a result of heavy rainfall in August and September.

The results of these studies indicate significant impact of climatic factors on the amount and quality of yields of this variety. However, despite the increasing influence of climate change, there are still very favourable agroecological conditions for growing Cabernet Sauvignon in Podgorica wine growing region.

\section{REFERENCES}

Božinović, Z. (2010): Ampelography. Book, Agrinet, Skopje

Brighenti, A. F., Rufato, L., Kretzschamar, A. A., Marcon Filho, J. L., Brighenti, L. M.,Malinovski, L. I., Da Silva, A. L. (2010): Phisical-Chemical Quality of Cabernet Sauvignon Clones in High Altitude Regionsw of Santa Catarina StateBrazil, 28th International Hortivcultural Congress, ISHS, Belgium, LisbonPortugal, vol. 2, pp. 722.

Burić, D. (1995): The modern viticulture, Nolit, Belgrade.

Cindrić, P., Korać, N., Kovač, V. (2000): The varieties of vines, Faculty of Agriculture, Novi Sad.

Gearheard, S., Pocernich, M., Stewart, R., Sanguya, J. and Huntington, H.P. (2010). Linking Inuit knowledge and meteorological station observations to understand changing wind patterns at Clyde River, Nunavut. Climatic Change, 100: 267-94

Jones, G.V. (2007): Climate change: observations, projections, and general implications for viticulture and wine production. P. 1-13. In: Proceedings of the Climate and Viticulture Congress, Zaragoza, Spain.

Jovovic, Z., Tiodorovic, Jelka, Velimirovic, Ana (2015): Climate change and crop production: The impact of floods on potato production in Montenegro. Symposium "Flood risk management and mitigation of their harmful effects," 4th June 2015, Sarajevo, Bosnia and Herzegovina, Proceedings, 135-140.

Jovovic, Z., Micev, B., Velimirovic, A. (2016): Impact of climate change on potato production in Montenegro and options to mitigate the adverse effects. Acad. J. Environ. Sci. 4(3): 047-054, West Yorkshire, England.

Micev, B. (2014): Climate change and floods. First National Platform for Disaster Risk Reduction, Podgorica.

Micev, B. (2015): Meteorological floods. II National Platform for Disaster Risk Reduction, Podgorica.

Miroševic, N, Jasminka Karoglan-Kontić (2008): Viticulture, Faculty of Agriculture, Zagreb. 
Mota, S. C., Talamini do Amarante, V. C, Pessoa dos Santos, H., Zanardi, Z.O (2008): Vegetative and Yield of Cabernet Sauvignon grapevine under overhead plastic covering. Revista Brasileira de Fruticultura, 30, 148-153.

Pajović, R., Popović, T., Boškov, K., Beleski, K (2009): Economic and technological characteristics of the grape variety Vranac and introduced varieties Cabernet Sauvignon and Merlot vin conditions of Podgorica wine growing region (Montenegro) and Skopje wine growing region (Macedonia). Agroznanje, vol. 10, no. 1. 89-95.

Pajović, R., Raičević, D., Popović, T., Sivilotti, P., Lisjak, K., Vanzo, A. 2014. Polyphenol Characterisation of Vranac, Kratosija and Cabernet Sauvignon (Vitis vinifera L. cv.) Grapes and Wines from Different Vineyard Locations in Montenegro. Afr. J. Enol. Vitic. 35, (1), 134-143.

Pejović, Lj.. Maraš, V., Mijović, S. (1996): A comparative study of the varieties Cabernet Sauvignon, Cabernet fran and Vranac in environmental conditions Podgorica, Agriculture, Belgrade, 383-386, 63-67.

Popović , T., Mijović, S., Pajović, R. (2013): The influence of climatic factors on the level and quality of yield of vranac variety in Podgorica vineyards. Agriculture and forestry, Vol.59., Issue 2: 137-145, Podgorica

Ranković-Vasić, Z., Atanacković, Z., Vujadinović, M., Vuković, A., Sivčev, B. (2011): The influence of climatic factors on the quality of the grape variety Pinot Noir in Vrsac vineyards, International Scientific Symposium of Agriculture "Agrosym Jahorina 2011", Proceedings, pp. 177-183, Jahorina.

Santalucia, G., Barbagall, M.G., Constanca, P., Di Lorenco, R., Pisciotta, A. (2007): Vegetative and Reproductive Behaviour of Vitis Vinifera L. ( Cv. Cabernet Sauvignon) Vines Growing under non-irrigated conditions and Moderate Water Stress Inducted By Different Irrigation Systems. Acta Hort. (ISHS) 754: 323-328.

Van Leeuwen, C., Seguin,G. (1994): Incidences de 1 alimentation en eau de la vigne, apreciee par 1 etat hidrique du feuillage, sur le developpment de appareil vegetatif et la maturation du raisin ( Vitis vinifera var. Cabernet Franc). J.Int. Sci. Vigne. Vin.28: 81-110.

Vukosavljević, V., Boškov, K., Pajović, R., Stojanov, M., Đurić, M., Murtić, S., Kojović, R. (2011): Yield potential and quality of variety Merlo in Trstenik vineyards. XII Conference on Biotechnology with international participation, Proceedings, Vol. 16 (18): 385-390. March 2011, Čačak, Serbija. 